DOI: http://dx.doi.org/10.24093/awejtls/vol1no1.9

\title{
Tense and Aspect in Translation from Arabic into English: Azazeelby Youssef Ziedan as a Case Study
}

\author{
Ebtisam Abdullah Alsaif \\ Department of English Language and Translation \\ College of Languages and Translation \\ King Saud University, Riyadh, Saudi Arabia
}

\begin{abstract}
The translation of tense and aspect between English and Arabic can be a challenge for translators because of the major differences in this respect between the two languages. In addition, there is lack in the translation literature of studies of authentic translations of tense and aspect from Arabic into English. The present study aims to fill this gap by examining the translation of tense and aspect from Arabic into English in a published translation made by a professional English translator. It also aims to clarify the evident confusion in understanding the categories of tense and aspect, particularly in languages that are as divergent as Arabic and English. In order to achieve these objectives, the researcher analyzed, compared, and explained examples drawn from selected chapters from Jonathan Wright's (2009) English translation of Youssef Ziedan's (2008) novel Azazeel. The researcher followed a descriptive analytical approach and, with the use of the quantitative approach, individually analyzed the English translations of the Arabic aspectual forms from Scrolls (chapters) One, Fourteen, and Twenty-four. The results of the study revealed that Wright's (2009) English equivalents of the Arabic aspectual forms in Azazeel were mostly accurate. The findings also showed through Wright's (2009) translation that there is not a standard approach to translate Arabic aspectual forms.
\end{abstract}

Keywords: aspect, imperfect, Modern Standard Arabic, perfect, tense, time

Cite as: Alsaif, E. A. (2017). Tense and Aspect in Translation from Arabic into English: Azazeelby Youssef Ziedan as a Case Study. Arab World English Journal for Translation \& Literary Studies, 1(1). DOI: http://dx.doi.org/10.24093/awejtls/vol1no1.9 